\title{
Studies on tolerance of chickpea to some pre and post-emergence herbicides
}

\author{
ljaz Ahmad Khan ${ }^{1 *}$, Rahamdad Khan², Amanullah Jan³, Syed Mehar Ali Shah ${ }^{4}$ \\ ${ }^{1}$ Department of Weed Science, The University of Agriculture, Peshawar-PAKISTAN, ${ }^{2}$ Department of Agriculture, Bacha Khan University, \\ Charsadda-PAKISTAN, ${ }^{3}$ Department of Agronomy, The University of Agriculture, Peshawar-PAKISTAN, ${ }^{4}$ Department of Plant Breeding and \\ Genetics, The University of Agriculture, Peshawar-PKISTAN
}

\section{A B S T R A C T}

\begin{abstract}
Herbicides application is an integral part of farmer's crop management in modern agricultural systems. Weeds always cause serious losses in legumes due to poor competition ability. In order to quantify the tolerance of chickpea against some pre and post-emergence herbicides, a pot study was carried out in the department of Weed science, The University of Agriculture, Peshawar Pakistan during 2012-13 and 2013-14. The pre emergence herbicides includes pendimethalin and s-metolachlor while, the post emergence herbicides comprised of Clodinafop-propargyl, fenoxaprop-p-ethyl and di-methyl urea. The chickpea variety Karak-I was sown in the pots and the trial was arranged in CR Design repeated three times. During the investigation data were recorded on different growth parameters of chickpea plants including both aerial and underground parts. The results revealed the all treatments had a significant effect on all the examined parameters of chickpea except nodule fresh and dry biomasses. However, the toxic effect of pre emergence herbicides on chickpea was significantly higher as compared to post emergence herbicides. The minimum number of nodule plant ${ }^{-1}(17.83)$, plant height $\left(50.50 \mathrm{~cm}^{2}\right.$, and seed protein (14.13\%) was recorded in Pendimethalin treated pots. However, the highest seed protein content of 21.75 and $21.15 \%$ were recorded for control and fenoxaprop-p-ethyl treatments respectively. Thus, it is concluded from the present data that chickpea has less tolerance for pre emergence herbicides pendimethalin and S-metolachlor as compared to post-emergence herbicides so farmers are advised to give preference to post emergence herbicides instead of a pre emergence while controlling weeds in chickpea through chemicals.
\end{abstract}

Keywords: Chickpea; Herbicides; Pre-emergence; Post-emergence; Protein; Weed.

\section{INTRODUCTION}

Chickpea (Cicer arietinum L.) mainly cultivated for human consumption with an annual area grown ranging between 9.30 and 12.65 million ha over the recent decade (FAO, 2016). Being a good source of protein, it plays important role in human diet for a large population in the developing world for a healthy daily food (Abbo et al., 2003). Annual crop legumes, grown in rotation with cereal crops, can improve yields of the cereals and contribute to the total pool of $\mathrm{N}$ in the soil (Fatima et al., 2008). In Pakistan, the chickpea is the most important pulse as well as a vegetable crop. On the basis of the seed colour and geographic distribution, chickpea has two main types, Desi and Kabuli. Nutritional imbalance and week nodulation appears to be the distinct ones, that can be effective only in a single croping season (Aslam et al., 2010).

The yield of chickpea in the developing countries is much more as compared to Pakistan, the factors which are responsible for low yield in Pakistan are poor soil, inadequate moisture, insensitive climatic conditions, weeds and insufficient or even no fertilizers supply (Aslam et al., 2007). Besides all other production constraints, the weeds strongly contribute in the yield reduction of chickpea because it is traditionally grown on residual soil moisture, therefore, weed competition poses a major problem in the water use efficiency. Loss in chickpea yield and yield components increased with increasing density of weeds (Whish et al., 2002). The most important weeds that infest the chickpea crop under rainfed conditions are Anagallis arvensis L., Lathyrus aphaca L., Convolvulus arvensis L., Cyperus rotundus L., Fumaria indica, Cynodon dactylon (L.) Pers, Medicago ploymorpha L., and Carthamus oxycantha L. (Saxena, 1976).

Various methods are used to control weeds in various crops, including manual, mechanical, cultural, biological and chemical. Weeding manually or through animal drawn implements like animal drawn seed drill, animal drawn

\footnotetext{
${ }^{*}$ Corresponding author:

Syed Mehar Ali Shah, Department of Weed Science, The University of Agriculture, Peshawar-PAKISTAN. E-mail: ijazahmadk@aup.edu.pk

Received: 14 January 2018; $\quad$ Accepted: 28 June 2018
} 
weeder and cultivator are effective, however, very expensive because of increased cost of labour and fuel. Chemical weed control is a good supplement to conventional methods and is an integral part of the modern crop production system (Patel et al., 2006). In case of severe weed infestation, the use of proper herbicide has become indispensable for the control of weeds, resulting in the diversion of nutrient and moisture to the major crop plants (Rahman et al., 2012). Chemical weed control method is preferred over other weed control methods because it is quicker, more effective and relatively cheaper (Shah et al., 1989). Weeds are controlled effectively by using selective herbicides. On the other hand, the continuous use of herbicides may cause weed resistance to herbicides and weed shift problem (Zhang, 2003).

Avola et al.(2008) verified that chemical control determine a significant depressive effect on plant height and grain yield ( $25 \%$ less than manual weeding and untreated plots), mainly resulted a lower number of seeds to germinate that determine a plant density lower than the planned one. Similarly Kumar and Singh. (2010) observed some morphological changes in plants while testing herbicides alone and in combination with other tank mix. Khan et al. (2004) also found a significant reduction in shoot length under the application of herbicide isoproturon and 2,4-D. Barker (2007) reported that the lowest plant height in herbicides treated plots was might be due to the fact that herbicides greatly reduced the weed infestation, but affect the plant by reducing the plant height and other growth parameters. The pre- emergence herbicides when applied to the soil that make the upper soil layer toxin that not only affect the weed seed germination but also inhibit the crop growth as well to a certain extend. Drew et al. (2007) reported that when legumes are exposed to several herbicides, reduced the nodulation and nitrogen fixation in these crops. Alvi et al. (2003) observed a remarkable reduction in protein content of Vigna radiata (L.) R. Wilczek) with the application of Atrazine.

Therefore, taking under consideration the herbicide injuries in legumes in term of growth retardation due to improper use of agro chemicals a pot study was initiated with the objective to assess the ill effect of different pre and postemergence herbicides on chickpea crop.

\section{MATERIAL AND METHODS}

Pot experiments were carried out during two consecutive years 2012-2013 and 2013-2014 at the Department of Weed Science, The University of Agriculture Peshawar Pakistan to evaluate the response of chickpea (Cicer arietinum L.) towards different pre and post-emergence herbicides.

\section{Seed collection}

The seed of chickpea variety Karak-I (Desi) was collected from the Agriculture Research Station, Ahmad Wala Karak, Khyber Pakhtunkhwa Pakistan during September, 2012. For minimizing the risk of germination failure and contamination, the seed was sun dried after cleaning.

\section{Experimental design and setup}

The experiments were laid out in completely randomized design (CRD) replicated three times. Total ten seeds of chickpea variety Karak-I was sown that later on thinned to six seedlings in each pot during both the studied years. The specification of each pot was $18.79 \mathrm{~cm}$ in height and $21.84 \mathrm{~cm}$ in diameter.

\section{Herbicide application}

Initially calibration was made to know the exact volume of water and herbicides with recommended doses were applied to each pot individually with a knapsack sprayer having a jet nozzle except the control pots. Herbicides applied along with dosage and time of application is given below in Table 1.

\section{Recorded parameters}

The data were recorded on the following parameters during the course of study:

Plant height $(\mathrm{cm})$, number of branches plant ${ }^{-1}$, number of pod plant ${ }^{-1}$, number of seeds plant ${ }^{-1}$, number of nodules plant $^{-1}$, nodule fresh weight plant ${ }^{-1}(\mathrm{~g})$, nodule dry weight plant $^{-1}(\mathrm{~g})$ and protein content of chickpea seed $(\%)$.

\section{Statistical analysis}

The recorded data for each parameter was subjected individually to the ANOVA technique by using MSTATC computer software and then LSD test was run at a probability level of 5\%. (Steel et al., 1997).

Table: 1 - Herbicides used, the dose and the time of application during pot experiment on chickpea

\begin{tabular}{|c|c|c|c|}
\hline Herbicides & Dose ha-1 & Application & Time/Stage \\
\hline S-metolachlor & $1 \mathrm{~L} \mathrm{ha}^{-1}$ & Pre-emergence & Direct after sowing \\
\hline Pendimethalin & $2.5 \mathrm{~L} \mathrm{ha}^{-1}$ & Pre-emergence & Direct after sowing \\
\hline Clodinafop-propargyl & $2 \mathrm{~kg} \mathrm{ha}^{-1}$ & Post-emergence & 45 DAS \\
\hline Fenoxaprop-p-ethyl & $2 \mathrm{~kg} \mathrm{ha}^{-1}$ & Post-emergence & 45 DAS \\
\hline Di-methyl urea & $1.85 \mathrm{~kg} \mathrm{ha}^{-1}$ & Post-emergence & 45 DAS \\
\hline No herbicide/Control & -------------- & -------------- & ------------------------ \\
\hline
\end{tabular}

* Days after sowing (DAS). 


\section{RESULTS AND DISCUSSION}

\section{Plant height $(\mathrm{cm})$}

The analysis of variance of the data revealed that both the pre and post-emergence herbicides had a variable effect on plant height as shown in Fig.1. From the perusal of the data it was observed that minimum numerical plant height $50.50 \mathrm{~cm}$ was recorded for pendimethalin treated pots followed by $53.66 \mathrm{~cm}$ in s-metolachlor that was statistically at par with di-methyl urea $(55.83 \mathrm{~cm})$. The maximum plant height $(60.33 \mathrm{~cm})$ was noted in weedy check which is statistically similar with Fenoxaprop-p-ethyl (58.16). The phytotoxic effect of herbicides on chickpea plant height demonstrated that pre-emergence herbicides (pendimethalinand s-metolachlor) had restricted the plant height more as compared to the post-emergence herbicides (clodinafop-propargyl, fenoxaprop-p-ethyl and di-methyl urea). The remarkable reduction in the growth of plant might be due to reduction in photosynthates production or slower the translocation of photosynthates to the tops (Qasim, 2005). Such depressive effect of herbicide on crop related parameters like plant height and number of pods plant $^{-1}$ was also being reported earlier by Barker, (2007) who stated that the lowest plant height in herbicides treated plots was might be due to the fact that herbicides greatly reduced the weed infestation but affect the plant by reducing the plant height and other growth parameters.

\section{Number of branches plant ${ }^{-1}$}

The crop canopy is one of the key parameters in term of photosynthates production. More branches and more fruits are expected to increase in canopy. In the present study the application of pre and post-emergence herbicides had a significantly more branch plant ${ }^{-1}$. Comparison of treatment means in Fig.2 reflects that the maximum branches plant ${ }^{-1}(5.00)$ was verified where no herbicide was applied, but that were statistically at par with postemergence herbicides (clodinafop-propargyl, fenoxapropp-ethyl and di-methyl urea). Minimum (2.66) number of branches per plant was observed in the pots treated

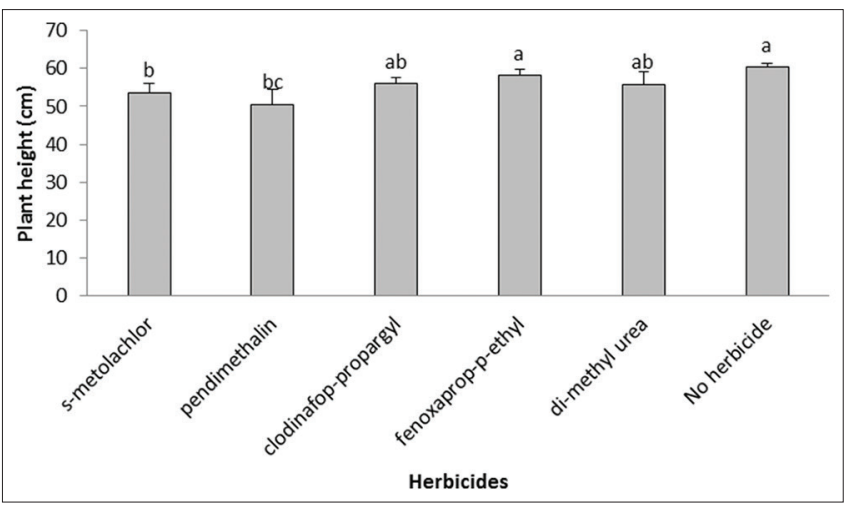

Fig.1. Chickpea plant height $(\mathrm{cm})$ as affected by different herbicides. with pre- emergence herbicide pendimethalin followed by s-metolachlor. In earlier studies Khan et al. (2006) also concluded that the application of several herbicide groups not only caused growth inhibition but also had deleterious morphological changes in whole plant or any particular plant organ. Similarly Kumar and Singh (2010) observed some morphological changes in plants while test herbicides alone and in combination with other tank mix. These findings indicated evidence of the negative impact of herbicides on plant growth parameters. Khan et al. (2004) also found significant reduction in shoot length under the application of herbicide isoproturon and 2,4-D. The current results are also in line with the previous work of Emenky et al. (2010) who reported the maximum number of branches plant ${ }^{-1}$ in non chemical weed management techniques as compared to herbicides.

\section{Number of pods plant ${ }^{-1}$}

Crop plant responds well only when all the required inputs having favorable environmental conditions are supplied. The mean value of the data revealed that herbicides had significant $(\mathrm{P} \leq 0.05)$ effect on number of pods plant ${ }^{-1}$ (Fig.3). s-metolachlor treated pots produced minimum (16.83) pods plant ${ }^{-1}$ followed by pendimethalin (17.83). High (19.50) No. of pods plant ${ }^{-1}$, were counted in the post application of clodinafop-propargyl followed by fenoxaprop-p-ethyl (19.33). The pre-emergence herbicides pendimethalin and s-metolachlor when applied to weeds in a field it might also affect the performance of actual crop plant due to its strong toxicity that leads to low No. of pods plant ${ }^{-1}$.

\section{Number of seeds plant ${ }^{-1}$}

It is a very common observation that when the number of productive seed pods ${ }^{-1}$ are more in leguminous plants the higher will be the seeds and vice versa. The present study (Fig.4) also showed the same trend like the previously discussed parameters and again the treatments; fenoxapropp-ethyl and control gave the maximum value for number of seeds plant ${ }^{-1}$. The data revealed that the maximum (29.66 and 29.00) seeds plant ${ }^{-1}$ were found for fenoxaprop-p-ethyl

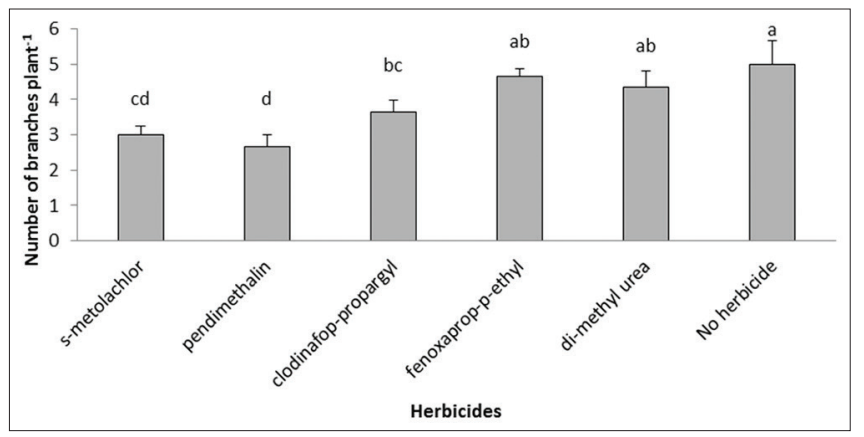

Fig.2. Chickpea number of branches plant ${ }^{-1}$ as affected by different herbicides. 


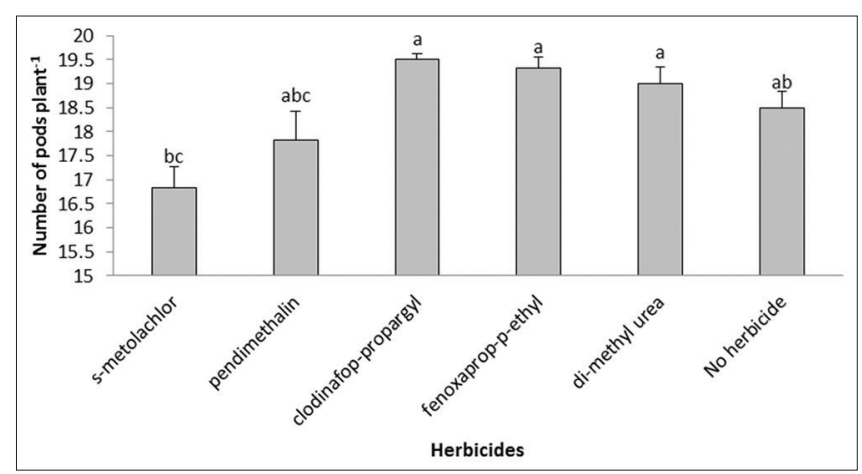

Fig.3. Chickpea number of pods plant $^{-1}$ as affected by different herbicides.

and control plots respectively. On the other hand minimum (23.66 and 23.67) number of seeds plant ${ }^{-1}$ calculated for pendimethalin and di-methyl urea respectively. Some time the herbicide toxicity showed long persistence and strong action against all kind of weeds, therefore due to the strong toxicity action fenoxaprop-p-ethyl are recommended to apply at early growth stage of weeds probably before reaching to five leaf stage (Mu et al., 2007). In the present study the post-emergence herbicide fenoxaprop-p-ethyl showed a little injury to the chickpea that probably due to the well establishment of the chickpea seedling before the application of fenoxaprop-p-ethyl as this herbicides applied as a post-application to the weeds and crop as well. While the pre-emergence herbicides when applied to the soil that make the upper soil layer toxic that not only affect the weed seed germination but also inhibit the crop growth as well to a certain extent. In other studies Khan et al. (2004) found considerable decline in chickpea yield when they applied the herbicides fluchloraline and 2,4-D. Moreover, they observed $46.3 \%$ and $45 \%$ yield reduction in chickpea, while applying high doses of fluchloraline.

\section{Number of nodule plant $^{-1}$}

Generally in legume plants number of nodules is considered as an index for accessing the fixation of $\mathrm{N}_{2}$ and efficiency of rhizobium specie. Therefore, it plays a fundamental role in the growth and development of a leguminous crop plant. Under the current investigation all the tested pre and post-emergence herbicides depicted variable results in term of nodule number. The data revealed that the maximum (21) nodule plant ${ }^{-1}$ was counted under the application of fenoxaprop-p-ethyl followed by clodinafop-propargyl (20) where as the least number of nodule plant ${ }^{-1}$ (17.83) were noted in pendimethalin (Fig. 5). Drew and Ballard. (2010) reported that when legumes are exposed to several herbicides that reduced the nodulation and nitrogen fixation in these crops. In addition the application of metribuzine strongly decreased the nitrogenase activity that can be related to the damage caused in the photosynthetic process and also the alteration in the nodule cortex structure (Fernandez et al., 1996). Likewise, the negative impact of

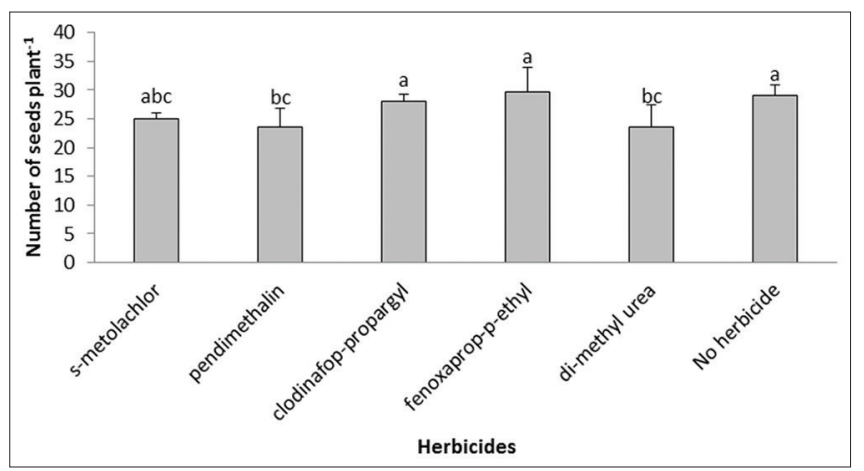

Fig.4. Chickpea number of pods plant ${ }^{-1}$ as affected by different herbicides.

herbicide applied treatments on nodulation and other related parameters in the leguminous plants are reported by different herbicides e.g. alachlor, metribuzine and trifluralin caused a reduction in nodulation in soyabean (Mallik and Tesfai, 1985). Moreover, the herbicidal application decline in nodulation might be due to the inhibition of symbiotic process between legume crop root and with the bacteria responsible for nitrogen fixation. However, the reduction in the nodulation could possibly be due to deceasing in nitrogenase activity that can be correlated with the photosynthetic apparatus disturbance with the nodule alteration (Zaidi et al., 2005). The application of commercial herbicides significantly declines the nitrogen content in the shoot possibly due to disturbance in nodule growth or hormones responsible for nodulation (Khan et al. 2004).

\section{Nodule fresh weight plant $^{-1}(\mathrm{~g})$}

The nitrogen fixing capability in legume can judge by the accumulation of fresh and dry matter in the nodule. The herbicide application in chickpea giving non-significant $(\mathrm{P} \leq 0.05)$ differences among the tested herbicides (Fig. 6). The analysis of the data showed that the highest (3.05 g) fresh nodule weight was recorded in clodinafop-propargyl followed by fenoxaprop-p-ethyl $(2.97 \mathrm{~g})$ where as the lowest nodule fresh weight $(2.80 \mathrm{~g})$ was recorded for control. The lower nodules in the herbicide treated pots might be due to limited nitrogenase activity in the affected soil or due to the leaves chlorosis of the chickpea that were unable to synthesize more glucose for the crop plant after exposed to herbicides. In earlier studies Datta et al. (2008) also reported that the most tolerant chickpea genotype received damaged when exposed to higher $\mathrm{pH}$ and herbicide rates and caused leaf chlorosis that significantly reduced plant height, nodulation and shoot and root dry weight. They further observed that the injurious impacts were more serious with the sensitive chickpea genotype than the tolerant one. In similar studies (Khan et al., 2011) reported that higher doses of herbicides suppressed the growth of root nodule bacterium (Mesorbizobium cicer). 


\section{Nodule dry weight plant ${ }^{-1}(\mathrm{~g})$}

Nodule dry weight plant ${ }^{-1}$ was not significantly affected by herbicidal treatments. The data in Fig. 7 exhibited that maximum $(0.154 \mathrm{~g})$ nodule dry weight was recorded in clodinafop-propargyl followed by fenoxaprop-p-ethyl $(0.152 \mathrm{~g})$ whereas, the lowest nodule fresh weight $(0.140 \mathrm{~g})$ was noticed for control pots. This reduction in the dry nodule weight indicates that the herbicide either interfere with the nodule initiation process or accumulation of the dry matter in the nodule. The low dry biomass of nodules might be due to the disturbance in the nitrogen fixation capability. In other studies Grossbard and Davies (1976) reported a non significant variation of the three tested herbicides on the fresh and dry weight of the nodule. These results are supported from the findings of Khan et al., (2004) who stated that root weight and the nodule number both reduced with the application of 2,4-D that indirectly affect the nodule dry weight accumulation. The present results are also in line with those of Datta et al. (2009) who found that isoxaflutole at the recommended rate had stunted plant growth $(29 \%)$, reduced shoot $(22 \%)$ and root $(50 \%)$ dry weights of the sensitive cultivar whereas, isoxaflutole had no effect on the growth parameters of the tolerant cultivar including root biomass. In addition isoxaflutole reduced total $\mathrm{N}$ content, nodulation (number and dry weight) and $\mathrm{N}$ fixation capacity of the sensitive cultivar.

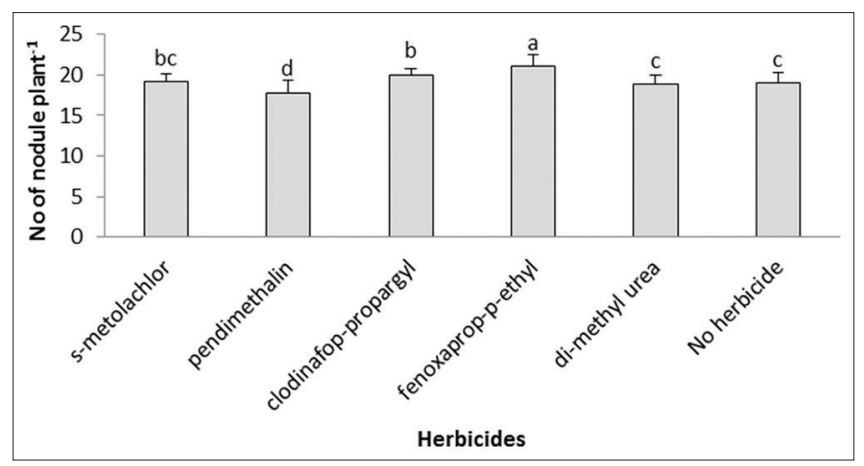

Fig.5. Chickpea number of pods plant ${ }^{-1}$ as affected by different herbicides.

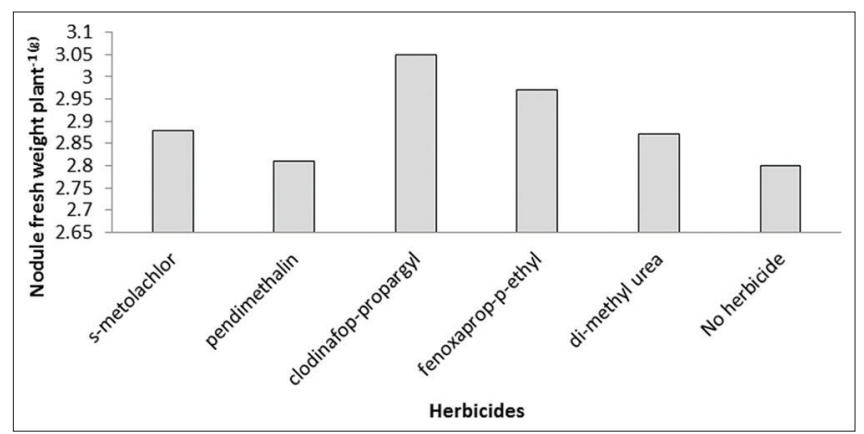

Fig.6. Chickpea number of pods plant $^{-1}$ as affected by different herbicides.

\section{Seed protein content}

Chickpea crop mostly popular for its high protein content across the world. The statistical analysis of the data revealed that all the tested pre and post-emergence herbicides $(\mathrm{P} \leq 0.05)$ significantly affect the seed protein $(\%)$ content. The pre-emergence herbicides adversely affect the seed protein content (Fig. 8). The results revealed that the maximum seed protein content $(21.75$ and $21.15 \%)$ was noted for control and fenoxaprop-p-ethyl treated pots, while the minimum seed protein $(14.1 \%)$ was noticed under the application of pendimethalin. The reduction in the protein content might be alteration in the biosynthesis pathway of protein due to interruption of toxic herbicidal molecules in the system or the herbicide brings alteration between mitotic variation in nucleic acid and protein synthesis Alvi et al. (2003). The other possibility, of protein reduction might be due to the damage to root vascular tissues that decrease or affect the supplier channel as a result low protein synthesis occurs (Parveen et al., 2002). Moreover, the direct effect of herbicides on seed protein or nucleic acid synthesis not been discovered yet because neither these sides or the primary site of action of any herbicides were known (Khan et al., 2006). The results are supported with the findings of Alvi et al. (2003) they also observed a reduction in protein content in legume seeds after the application of herbicide Atrazine. The decreased in protein and amino acid contents indicate that pesticide

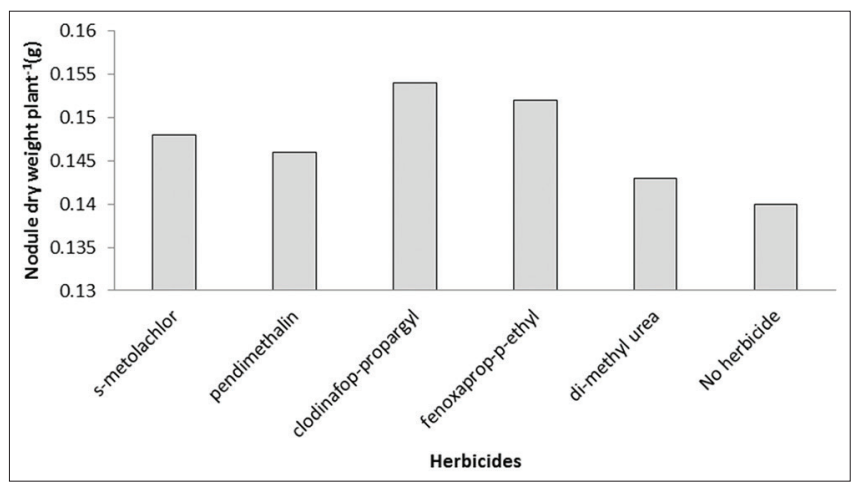

Fig.7. Chickpea dry nodule biomass plant $^{-1}(\mathrm{~g})$ as affected by different herbicides.

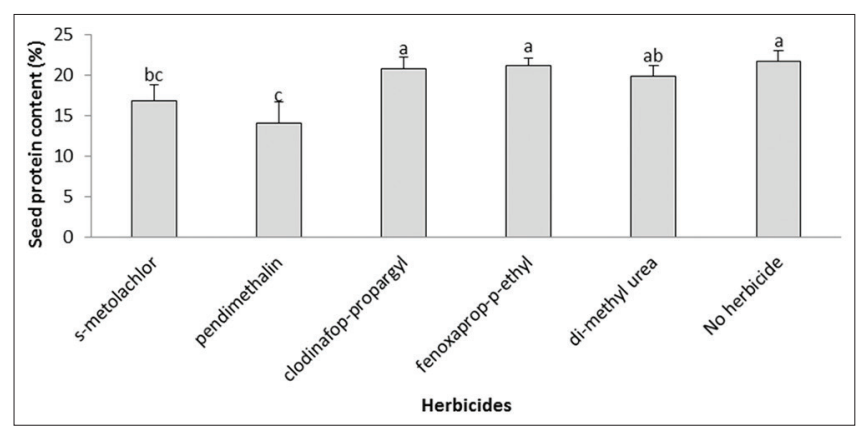

Fig.8. Chickpea seed protein content (\%) as affected by different herbicides. 
application disturbs nitrogen metabolism (Saladin et al., 2003). Similarly, Hassan (2000) also attributed reduction in the seed protein content to alteration in the chemistry of protein biosynthesis process.

\section{CONCULSIONS}

The tolerance of chickpea against some pre emergence herbicides i.e., pendimethalin and s-metolachlor was weaker as compared to post-emergence herbicides under the study. Depressive effect on plant height and grain yield (25\% less than manual weeding and untreated plots), mainly resulted a lower number of seeds or arrest plant growth. The present research also provides a clue to the farming community by drawing their attention towards the judicious use of herbicides and minimizing its application in legumes especially chickpea crop. We recommended from the present findings that the farmers of the concerned chickpea growing area may be educated regarding the appropriate use of agro chemicals to overcome the losses in chickpea crop caused due to herbicide injuries. Moreover, similar experiments with varying chickpea varieties and different treatments should be carried out in different climatic zones (Cold and warmer regions) of the country to confirm the present findings and determine the range of validity of the present findings.

\section{ACKNOWLEDGEMENTS}

We gratefully acknowledge the Higher Education Commission, Pakistan for providing financial support under Indigenous Ph.D. fellowship programme.

\section{REFERENCES}

Abbo, S., J. Berger and N. C. Turner. 2003. Evolution of cultivated chickpea: Four bottlenecks limit diversity and constrain adaptation. Funct. Plant Biol. 30: 1081-1087.

Alvi, S., R. Perveev, I. M. Naqvi and S. S. Shaukat. 2003. Effect of atrazine on absorption and translocation of P32, chlorophyll, carbohydrate, protein and potassium contents in bean Vigna radiata (L.) Wilczek. Asian J. Plant Sci. 6(3): 249-251.

Aslam, M., H. K. Ahamd, E. Ahamd, H. M. A. Khan and A.G. Sagoo. 2007. Effect of sowing methods and weed control techniques on yield and yield components of chickpea. Pak. J. Weed. Sci. Res. 13(1-2): 49-61.

Aslam, M., H. K. Ahmad, H. Ullah, M. Ayaz, E. Ahmad, A. G. Sagoo, I. Ullah, A. Hussain and M. Manzoor. 2010. Nodulation grain yield and grain protein contents as affected by rhizobium inoculatioin and fertilizer placement in chickpea cultivar bittle-98. Sarhad J. Agric. 26(4): 467-474.

Avola, G., R. Tuttobene, F. Gresta and V. Abbate. 2008. Weed control strategies for grain legumes. Agron. Sustain. Dev. 28(1): 389-395.

Barker, B. 2007. Broadleaf Weed Control in Chickpeas Shows Potential. Available from: http://www.topcropmanager.com/ content/view/1010/67/.

Datta, A., M. Brian, A. C. Sindel, P. Kristiansen, R. S. Jessop and W. L. Felton. 2009. Effect of isoxaflutole on the growth, nodulation and nitrogen fixation of chickpea (Cicer arietinum L.). Crop Protec. 28: 923-927.

Datta, A., M. Brian, A. C. Sindel, P. Kristiansen, R. S. Jessop and W. L. Felton. 2008. The effect of soil pH on chickpea (Cicer arietinum) genotype sensitivity to isoxaflutole. J. Plant Soil, 303(1): 49-54.

Drew, E. A., V. V. S. R. Gupta and D. K. Roget. 2007. Herbicide use, productivity, and nitrogen fixation in field pea (Pisum sativum). Australian J. Agril. Res. 58: 1204-1214.

Drew, E and R. Ballard. 2010. Improving N2 fixation from the plant down: Compatibility of Trifolium subterraneum L. Cultivars with soil rhizobia can influence symbiotic performance. Plant Soil. 327: 261-277.

Emenky, F. A., O. Ahmed, S. Khalaf and N. M. Salim. 2010. Influence of tillage and weed management methods on chickpea (Cicer arietinum L.) yield and yield components. Pak. J. Weed Sci. Res. 16(2): 189-198.

FAO. (2016). Available from: http://www.fao.org/faostat/en/\#data/QC. [Last accessed on 28 Feb 2018].

Fatima, Z., A. Bano, R. Sial and M. Aslam. 2008. Response of chickpea to plant growth regulators on nitrogen fixation and yield. Pak. J. Bot. 40(5): 2005-2013.

Fernández, P. M. C., C. D. Lorenzo, H. Sixto, J. M. Pozuelo, L. Guasch and M. R. D. Felipe. 1996. Photosynthetic and nitrogenase activities in Lupinus albus plants treated with herbicides from different chemical groups. In Proc. Intern. Symp. Weed and Crop Resist. to Herb, pp. 134-136.

Grossbard, E and H. A. Davies. 1976. Specific microbial responses to herbicides. Weed Res. 16 (3): 163-170.

Hassan, H. Z. 2000. Effects of stimufol fertilizer on post-cytological abnormalities and protein profile alterations induced by nuvacron insecticide. Proc. 1st Inter. Conf. on Bio. Sci. (ICBS) Faculty of Science, Tanta University,pp. 448-466.

Khan, I. M., G. Hassan, I. Khan and K. B. Marwat. 2011. Testing of herbicides at various doses on the growth stages of wild onion grown in pots. Sarhad J. Agric. 27(1): 85-91.

Khan, M. S., A. Zaidi and M. Aamil. 2004. Influence of herbicides on chickpea-mesorhizobium symbiosis. Agron. 24 (3): 123-127.

Khan, M. S., P. Chaudhry, P. A. Wani and A. Zaidi. 2006. Biotoxic effects of the herbicides on growth, seed yield, and grain protein of Greengram. J. Applied Sci. Environ. Manag. 10(3): 141-146.

Kumar, S and A. K. Singh. 2010. A review on herbicide 2,4-D damage reports in wheat (Triticum aestivum L.). J. Chem. Pharm. Res. 2(6): 118-124.

Mallik, M. A. B and K. Tesfai. 1985. Pesticidal effect on soybeanrhizobium symbiosis. Plant Soil. 85: 33-41.

Mu, J. W., L. Peng and L. D. Ping. 2007. Studies on herbicide application by stage to control barnyard grass in paddy field of cold region. Beifang Shuidao. 6: 40-42.

Patel, B. D., V. J. Patel, J. B. Patel and R. B. Patel. 2006. Effect of fertilizers and weed management practices on weed control in chickpea (Cicer arietinum L.) under middle Gujarat conditions. Indian J. Crop Sci. 1(1-2): 180-183.

Parveen, R., S. S. Shaukat and I. I. Naqvi. 2002. Effect of atrazine on carbohydrates, potassium, sodium, phosphate and amino acid contents in bean Vigna radiata (L.) Wilczek. Asian J. of Plant Sci. 1(5): 552-553.

Qasim, J. R. 2005. Chemical control of weeds in onion (Allium cepa L.). J. Horti. Sci. Biotech. 80(6): 721-726. 
Rahman, Q. W. U., M. S. Shahenshah, H. Khan, Q. L. U. Rahman, D. Ahmad, F. Wahid and Z. Muhammad. 2012. Effect of different herbicides and row spacings on the growth and yield of tomato (Lycopersicon esculentum L.). Pak. J. Weed Sci. Res. 18(2): 157-165.

Robinson, M. 2009. Re-evaluating the Role of Herbicide in Contemporary Urban Horticulture. International Symposium on Urban Tree Health, Paris France.

Saladin, G., C. Magne and C. Clement. 2003. Stress reactions in Vitis vinifera $\mathrm{L}$. Following soil application of the herbicide flumioxazin. Chemosphere. 53: 199-206.

Saxena, M. C. and D. S. Yadav. 1976. Proc. Inter. Workshop on Grain legumes, ICRISAT. Hyderabad India, pp. 31-61.

Shah, M. I., A. Jalis, M. Ramzan and J. Iqbal. 1989. Chemical weed control in broadcast sown wheat under irrigated conditions. J. Agric. Res. 3: 195-199.

Steel, R. G. D., J. H. Torrie and D. Dicky. 1997. Principles and Procedures of Statistics. Multiple Comparison. 3rd Ed. McGraw Hill Book Co., New York, USA, pp. 178-198.

Whish, J. P. M., B. M. Sindel, R. S. Jessop and W. L. Felton. 2002. The effect of row spacing and weed density on yield loss of chickpea. Aust. J. Agric. Res. 53(12): 1335-1340.

Zaidi, A., M. S. Khan and P. Q. Rizvi. 2005. Effect of herbicides on growth, nodulation and nitrogen content of greengram. Agron. Sustain. Dev. 25: 497-504.

Zhang, Z. P. 2003. Development of chemical weed control and integrated weed management in China. Weed Biol. Manag. 3(4): 197-203. 